\title{
Kondisi Sosial Rakyat Suriah Pasca Revolusi 2011 Dalam Novel Ayyām Fī Bābā 'Amrū Karya Abdullah Maksūr: Analisis Sosiologi Sastra
}

\author{
Nurul Istiqomah \\ STKIP Harapan Bima, Bima, Indonesia \\ *Email: nurul.istiqomah@ @abi.ac.id
}

\begin{abstract}
Ayyām fì Bābā 'Amrū novel by Abdullah Maksūr is one of novels that came out after the Arab Spring that hit Syria. The revolution in Syria occurred because of the people's desire to overthrow al-Assad regime which had been in power for decades. Demonstrations in Syria then ended into a civil war that never ended until now. This novel takes the story of the condition of Syrian society after the Syrian revolution erupted in 2011 and describes the conflict between the military and the Syrian people. This study aims to reveal the social conditions experienced by Syrians of the Syrian revolution based on data in the Ayyām fi Bāba 'Amrū novel, the social reality of Syrian society, and the relationship between the structure of the text and the social reality of Syrian society. The theory used in this study is Alan Swingewood's the sociology of literature theory with the concept that literary work is a mirror of the age. The method used is the literary of sociology method which is a moving method of literary data. The results of this study indicate that there are several causes of the Syrian revolution mentioned in the novel, such as the desire to be free from a regime that has been in power for decades, corruptions, inspired by other Arab countries, and a long-held hatred. The social conditions experienced by the Syrian people during the revolution were experiencing intimidation from the military, the people were arrested without any fault, some Syrians were tortured in military prisons, shootings, bombings and chaos in several cities, some girls experienced sexual harassment, the people were divided between supporting the regime or opposition, and most Syrians flee to neighboring countries. The social condition that occurs in the novel is a representation of the social reality that occurred in Syrian society after the revolution in 2011.
\end{abstract}

Keywords: Ayyām F̄̄ Bābā 'Amrū, Society, Syrian Revolution, Sociology Of Literature.

Abstrak. Novel Ayyām fì Bābā 'Amrū karya Abdullah Maksūr merupakan salah satu novel yang terbit setelah Arab Spring yang melanda Suriah. Novel ini mengangkat cerita mengenai kondisi masyarakat Suriah pasca meletusnya revolusi Suriah tahun 2011 dan menggambarkan konflik yang terjadi antara militer dengan rakyat Suriah. Penelitian ini bertujuan untuk mengungkap kondisi sosial yang dialami masyarakat Suriah pada masa revolusi Suriah berdasarkan data dalam novel Ayyām $f i$ $B \bar{a} b \bar{a}$ 'Amrū, realita sosial masyarakat Suriah, dan relasi antara struktur teks dengan realita sosial masyarakat Suriah. Teori yang digunakan dalam penelitian ini adalah teori sosiologi sastra Alan Swingewood dengan konsep bahwa karya sastra merupakan cermin zaman. Adapun metode yang digunakan adalah metode literary of sociology yang merupakan metode analisis yang bergerak dari data-data karya sastra. Hasil penelitian ini menunjukkan bahwa ada beberapa penyebab terjadinya revolusi Suriah yang disebutkan dalam novel, seperti keinginan untuk bebas dari rezim yang telah berkuasa puluhan tahun, korupsi yang merajalela, terinspirasi dari negara-negara Arab lainnya, dan kebencian yang telah tertanam sejak lama. Adapun kondisi sosial yang dialami masyarakat Suriah pada masa revolusi adalah mengalami intimidasi dari militer, rakyat ditangkap tanpa kesalahan, mendapat penyiksaan di penjara militer, terjadi penembakan, pengeboman, dan kekacauan di beberapa kota, beberapa gadis mengalami pelecehan seksual, rakyat terpecah belah antara mendukung rezim atau oposisi, dan sebagian besar rakyat Suriah mengungsi ke negara-negara tetangga. Kondisi sosial yang terjadi di dalam novel memiliki homologi dengan realita sosial yang terjadi di masyarakat Suriah pasca revolusi tahun 2011.

Kata kunci: Ayyām fì Bābā 'Amrū, masyarakat, revolusi Suriah, sosiologi sastra. 


\section{PENDAHULUAN}

Pada akhir tahun 2010 hingga pertengahan tahun 2011, Timur Tengah dan Afrika Utara mengalami revolusi atau yang terkenal dengan nama Arab Spring. Arab Spring atau Musim Semi di Timur Tengah dan Afrika Utara merupakan harapan baru bagi rakyat untuk terbentuknya era kepemimpinan yang lebih demokratis. Tunisia menjadi negara pertama yang melakukan revolusi pada 17 Desember 2010 yang diawali oleh tindakan Muhammad Bouazizi yang nekat membakar dirinya di depan kantor pemerintah setempat (Kuncahyono, 2013:2). Tindakan Bouazizi menjadi awal keberanian rakyat untuk melawan rezim Zine elAbidin Ben Ali dan berhasil menggulingkan rezim Ben Ali pada 14 Januari 2011.

Pergolakan yang terjadi di Tunisia kemudian menyebar ke seluruh negara-negara Afrika Utara dan Timur Tengah. Mesir menyusul melakukan aksi protes dengan tujuan menggulingkan kepemimpinan presiden Husni Mubarak yang telah berkuasa selama 30 tahun. Hingga akhirnya pada 11 Februari 2011, presiden Husni Mubarak menyatakan mundur dari kursi kepresidenan. Setelah Mesir, Libya menyusul untuk menumbangkan rezim Muammar Khadafy yang telah berkuasa selama 40 tahun hingga Khadafy terbunuh di tangan rakyatnya sendiri (Kuncahyono, 2013:8).

Adapun konflik Suriah dimulai dengan munculnya coretan-coretan di tembok sekolah yang dilakukan oleh 15 orang anak yang berusia antara 15-19 tahun pada Maret 2011 di kota Dar'aa yang terletak di sebelah tenggara Suriah. Anak-anak ini terinspirasi oleh kejadian yang terjadi di Tunisia yang menggulingkan kepemimpinan presiden Zine el-Abidin Ben Ali dan di Mesir yang berhasil menggulingkan kepemimpinan presiden Husni Mubarak. Anakanak ini menulis graffiti dengan kata-kata asySya'ab yurīd isqāt al-Nizâami (rakyat ingin menumbangkan rezim) (Setiawati, 2012:5). Jendral Atif Najib yang merupakan kepala kepolisian sekaligus sepupu Bashar al-Assad menangkap dan memenjarakan remaja-remaja ini. Anak-anak ini dipenjara dan disiksa selama sebulan. Hal ini membuat protes untuk pembebasan remaja-remaja ini menyebar. Reaksi tentara yang berlebihan dengan menembaki demonstran membuat gelombang protes semakin menyebar ke beberapa kota, seperti Latakia, Banyas, Homs, Hama, dan Deir es Zor (Setiawati, 2012:5).

Dengan adanya faktor kemiskinan, pengangguran, dan nepotisme yang merugikan sebagian besar masyarakat Suriah menjadi pemicu paling mudah untuk mengobarkan revolusi. Akan tetapi, berbeda dengan revolusi Mesir dan Tunisia yang berhasil menggulingkan rezim yang berkuasa, revolusi Suriah berkembang menjadi perang sipil yang masih berlangsung hingga saat ini. Pada tahun 2014 konflik Suriah tercatat telah menewaskan ratusan ribu jiwa, 6.5 juta penduduk Suriah meninggalkan kampung halaman mereka, dan 2.7 juta jiwa mengungsi ke negara-negara tetangga (Fahham dan Kartaatmaja, 2014:47-48).

Kondisi sosial yang dialami oleh rakyat Suriah kemudian diangkat oleh beberapa novelis, salah satunya Abdullah Maksūr, ke dalam karya sastra. Karya sastra diciptakan oleh sastrawan berdasarkan apa yang terjadi dalam masyarakat. Sastrawan yang melahirkan karya sastra merupakan makhluk sosial yang dipengaruhi oleh masyarakat dan lingkungan sosialnya. Dalam lingkungan sosial, pikiran dan ekspresi pengarang dibentuk. Maksūr kemudian menggambarkan kondisi sosial dan tragedi kemanusiaan yang dialami rakyat Suriah dalam novelnya yang berjudul Ayyām fì Bābā 'Amrū. Novel ini menceritakan tentang tokoh Aku yang merupakan seorang jurnalis. Ia kembali ke Suriah pasca meletusnya aksi protes terhadap rezim alAssad untuk membuat film dokumenter mengenai revolusi Suriah. Tokoh Aku kemudian mengalami berbagai kejadian, seperti ditangkap dan disiksa oleh mukhābarāt dan menjadi saksi berbagai kejadian di Homs dan Hama, seperti kekacauan, kerusuhan, pengeboman, penangkapan, dan penyiksaan yang dialami oleh rakyat Suriah pasca meletusnya revolusi tahun 2011.

Novel Ayyām fì Bābā 'Amrū akan diteliti menggunakan teori yang relevan, yakni sosiologi sastra. Hal ini dilakukan karena adanya relevansi antara novel dengan kenyataan yang terjadi sehari-hari di Suriah, yakni adanya gejala dan struktur sosial yang menampilkan kondisi sosial masyarakat Suriah pada masa revolusi. 


\section{METODE PENELITIAN}

Teori yang digunakan dalam penelitian ini adalah teori sosiologi sastra Alan Swingewood. Teori sosiologi sastra digunakan untuk mengungkap struktrur sosial dalam novel dan menghubungkannya dengan realita sosial yang terjadi. Swingewood menawarkan tiga perspektif mengenai sosiologi sastra, yakni penelitian yang memandang sastra sebagai refleksi (cermin) zaman saat karya sastra tersebut diciptakan, penelitian yang memandang karya sastra dari proses produksi dan kepengarangan, dan penelitian yang memandang karya sastra dalam hubungannya dengan kesejarahan dan penerimaan pembaca (Swingewood dan Laurenson, 1972:13-15). Ketiga perspektif ini dapat digunakan bersamaan atau terpisah sesuai dengan sasaran yang diinginkan dalam penelitian.

Pertama, penelitian yang memandang karya sastra sebagai cermin zaman. Perspektif ini merupakan perspektif yang paling terkenal seperti yang disampaikan Swingewood dalam bukunya The Sociology of Literature, the most popular perspective adopts the documentary aspect of literature, arguing that it provides a mirror of the age (Swingewood dan Laurenson, 1972:13). Swingewood berpendapat bahwa karya sastra merupakan dokumen sosial budaya yang dapat digunakan untuk melihat fenomena yang terjadi dalam masyarakat pada masa tersebut. Swingewood menganalogikan karya sastra sebagai pantulan dari refleksi masyakarakat, seperti struktur sosial, hubungan kekeluargaan, tren yang muncul, dan konflik kelas (Swingewood dan Laurenson, 1972:13).

Kedua, penelitian yang memandang karya sastra dari sisi kepengarangan dan produksi. Pendekataan kedua ini keluar dari teks menuju proses produksi karya terutama situasi sosial pengarang yang juga mempengaruhi karya. Selain itu, seiring berkembangnya era industri, fenomena pasar memudahkan pengarang untuk mendapat royalti yang kemudian melemahkan tematik sastra yang sebelumnya menjadi bahan penilaian suatu karya. Dalam hal ini, yang perlu diperhatikan adalah kehidupan sosial pengarang, bagaimana ia menjalani profesinya, selera pasar, dan lain sebagainya.

Ketiga, penelitian yang memandang karya sastra dari segi penerimaan pembaca. Untuk menggunakan konsep ini, dibutuhkan kemampuan level tinggi karena konsep ini digunakan untuk melacak penerimaan karya sastra pada masyarakat tertentu dan pada momen sejarah tertentu. Konsep ketiga ini fokus pada penerimaan masyarakat terhadap suatu karya sastra.

Metode yang digunakan dalam mengumpulkan data adalah metode kepustakaan (library research) yakni dengan membaca literatur-literatur yang berhubungan dengan data. Adapun metode yang digunakan untuk mengalisis data adalah metode yang ditawarkan oleh Alan Swingewood dalam teori sosiologi sastra. Metode yang ditawarkan Swingewood ada dua, yakni metode sociology of literature dan literary sociology. Sociology of literature merupakan metode yang bergerak dari realita sosial di luar karya sastra. Adapun metode literary sociology adalah metode yang bergerak dari data-data yang terdapat dalam karya sastra. Metode yang digunakan dalam penelitian ini adalah metode literary sociology yang berangkat dari data-data karya sastra dan menghubungkannya dengan realita sosial yang terjadi.

\section{HASIL DAN PEMBAHASAN}

Swingewood

(1972:

15-17), mengemukakan bahwa konteks sosial budaya masyarakat merupakan hal yang tidak dapat dipisahkan dari kelahiran karya sastra. Hal ini berdasarkan pandangan bahwa karya sastra merupakan suatu fenomena kebudayaan dan produk sosial suatu masyarakat sehingga karya sastra disebut sebagai cerminan masyarakat dan kondisi sosial yang dialami oleh penulis. Karya sastra tidak lahir dari kekosongan budaya, karena itu karya sastra yang diciptakan oleh pengarang tidak dapat terlepas dari masyarakat dan budaya yang melingkupinya. Sebuah karya sastra tidak dapat dipahami secara lengkap jika dipisahkan dari lingkungan atau kebudayaan atau peradaban yang telah menghasilkannya (Damono, 1979:4). Novel Ayyām fì Bābā 'Amrū terbit pasca meletusnya revolusi Suriah. Novel ini 
menggambarkan mengenai kondisi sosial yang terjadi di Suriah pasca revolusi. Selain itu, novel ini juga menggambarkan mengenai beberapa penyebab terjadinya revolusi Suriah.

\section{Faktor Penyebab Revolusi Suriah}

Rezim Suriah didominasi oleh Alawiyah yang merupakan sekte minoritas yang selalu menggambarkan diri mereka sebagai pelindung semua minoritas di Suriah (Lesch, 2012:83). Sebelum Bashar al-Assad menjadi presiden Suriah, ayahnya, Hafiz al-Assad, telah menjadi presiden Suriah selama hampir 30 tahun sejak tahun 1971-2000. Setelah kematian ayahnya, Bashar al-Assad menjadi presiden Suriah setelah memenangkan pemilihan presiden pada Juli 2000. Sejak awal 1970-an, Suriah dipimpin oleh Hafiz al-Assad yang merupakan seorang militer. Ia memimpin Suriah dengan semi-otoriter. Ia menempatkan mata-mata dan intelijen untuk mengawasi rakyat Suriah. Rakyat Suriah harus mengikuti apa yang diatur oleh rezim dan yang dianggap melanggar dan memprotes kemudian akan ditangkap oleh intelijen.

Rezim yang otoriter membuat korupsi tumbuh subur di Suriah. Menurut al-Sheikh dan Abdullah (tanpa tahun:4-5) penyebab utama korupsi yang marak terjadi di Suriah adalah karena pemerintah. Jika rezim pemerintah menuju kediktatoran, maka korupsi akan tumbuh subur. Dengan meningkatnya kepemimpinan yang otoriter, maka demokrasi lenyap dan otoritas hanya terbatas kepada pemegang kekuasaan. Konflik yang terjadi dalam struktur pemerintahan menyebabkan korupsi meningkat di berbagai level, seperti keuangan, administratif, ekonomi, dan sosial. Korupsi telah meningkat di semua sistem di Suriah karena rakyat mendukung dan mengidolakan pemimpin tanpa memperhatikan konsep negara modern dan demokrasi. Korupsi yang umumnya terjadi di Suriah adalah suap-menyuap, penyalahgunaan kekuasaan, dan penggelapan dana publik. Hal ini terlihat dalam kutipan berikut.

$$
\begin{aligned}
& \text { في السجن المركزي كما قال لي هناك خيار وفقوس } \\
& \text { أي بمقدار النقود يكون النفوذ فبإمكانك أن تحيا لتحيا حياة }
\end{aligned}
$$

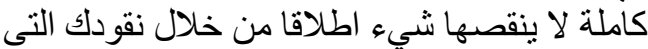

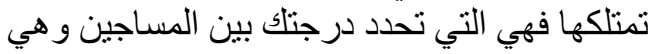

$$
\begin{aligned}
& \text { التي تعطيك الصناحية في النوم على السرير } \\
& \text { و الإستحمام بالماء الساخن و أكل أطايب الطعام، الطرئ }
\end{aligned}
$$

$$
\begin{aligned}
& \text { السجن كأي مؤسسة في الدولة قد نخره الفساد من } \\
& \text { رأسه حتى أخمص قدمينه، }
\end{aligned}
$$

(Maksūr, 2013:56-57)

'Di penjara pusat, seperti yang diceritakan 'Urwah kepadaku, ada pilihan sesuai dengan kemampuan membayar sejumlah uang, maka kamu mungkin akan hidup dengan nyaman tanpa kekurangan sesuatu apapun selama kamu memiliki uang. Uang yang kamu miliki itu akan menentukan posisimu di antara para nara pidana. Uang itu memberikanmu kenyamanan untuk tidur di ranjang busa, mandi air hangat, dan makan makanan yang terbaik. Penjara itu sama seperti lembaga-lembaga lain di negara ini yang telah rusak dari ujung kepala hingga ujung kaki.'

Alasan lain meletusnya Arab Spring di Suriah adalah karena Arab Spring yang melanda Timur Tengah dan Afrika Utara yang dimulai dari Tunisia dan diikuti oleh negara-negara lainnya, seperti Mesir dan Libya. Rakyat Suriah memantau pergolakan dan revolusi di negaranegara tersebut dan mengadopsi hal tersebut ke Suriah. Rakyat ingin menumbangkan rezim alAssad yang telah berkuasa puluhan tahun seperti yang terjadi pada rezim Zine al-Abidin Ben Ali dan Husni Mubarak. Hal tersebut terlihat dalam kutipan berikut.

$$
\begin{aligned}
& \text { وعلى الضفة الأخرى كان المنظاهرين قد حسموا الأمر }
\end{aligned}
$$

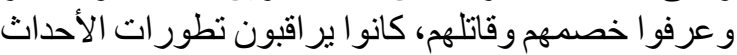

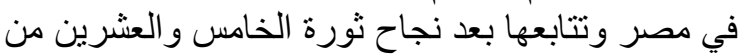

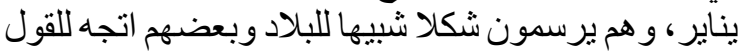

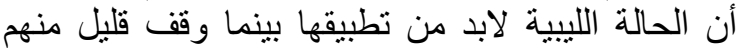

$$
\begin{aligned}
& \text { يتأملون التجربة التونسية طامحين لتطبيقها، لإن }
\end{aligned}
$$

(Maksūr, 2013:56)

'Sementara itu, kelompok demonstran telah memutuskan dan mengetahui siapa lawan mereka. Mereka mengikuti perkembangan kejadian di Mesir dan mengikutinya setelah kemenangan revolusi 25 Januari. Mereka juga mengikuti pola revolusi yang terjadi di negara tersebut. Sebagian lagi mengarah pada pandangan bahwa revolusi di Libya harus diterapkan, sedangkan sebagian lagi memperhatikan upaya revolusi di Tunisia dan bersiap untuk mengikutinya.' 
Selain itu, telah ada kenbencian rakyat terhadap rezim yang mengendap lama. Konflik antara rezim dan rakyat terjadi sejak masa Hafiz al-Assad yang diktator. Pada Februari tahun 1982, Hafiz al-Assad menyerang kota Hama yang merupakan basis Ikhwan al-Muslimin karena dianggap membahayakan kepemimpinannya. Militer di bawah perintah Hafiz al-Assad menyerang dan mengangkap orang-orang yang dianggap berafiliasi dengan Ikhwan al-Muslimin. Banyak orang-orang yang tidak bersalah kemudian menjadi korban dalam penyerangan ini. Rakyat Suriah yang kehilangan anggota keluarga dalam penyerangan ini berusaha mencari tahu tentang kondisi anggota keluarga mereka. Hal tersebut dimanfaatkan oleh sipir penjara untuk menjual informasi mengenai para tahanan kepada anggota keluarga mereka.

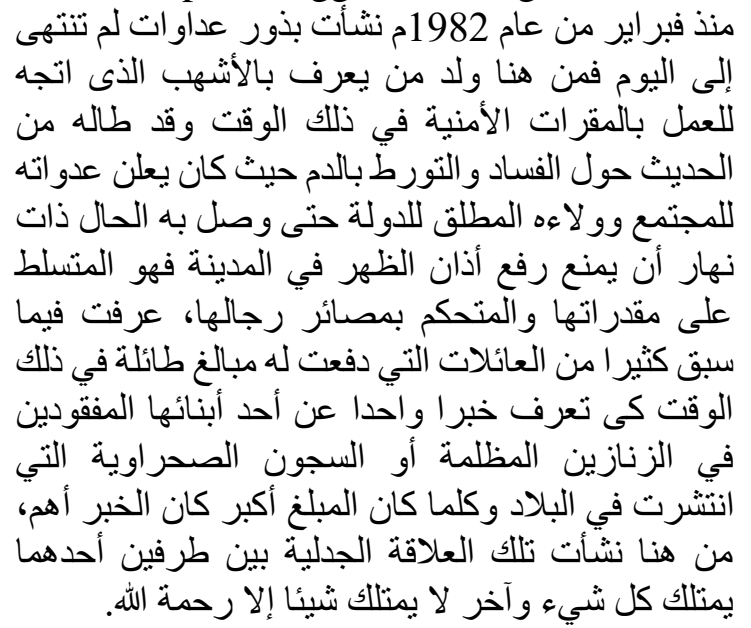

(Maksūr, 2013:171-172)

'Sejak Februari 1982 tumbuh bibit kebencian yang tidak berakhir hingga hari ini. Dari sini (Hama), ada seorang laki-laki yang dikenal Asyhab yang bekerja di kantor keamanan pada saat itu dan telah banyak yang menceritakan kerusakan dan kekerasan yang mana dia mengumumkan permusuhannya dengan masyarakat dan kesetiaannya yang mutlak kepada negara, hingga dia bahkan berani melarang masyarakat untuk mengumandangkan adzan Dzuhur di kota dan dia adalah penguasa saat itu dan berkuasa dalam menentukan takdir orang-orangnya. Aku tahu bahwa banyak keluarga yang harus membayar denda dengan banyak pada saat itu agar mereka mengetahui kabar dari salah satu anak mereka yang hilang di sel yang gelap atau di penjara gurun yang tersebar di seluruh negeri. Setiap kali jumlah yang harus dibayarkan lebih besar, maka berita yang diberikan sangat penting. Dari sinilah timbul hubungan permusuhan antara dua kubu, yang satu memiliki segalanya sedangkan yang satu lagi tidak memiliki apapun selain rahmat Allah.'

\section{Kondisi Sosial Pasca Meletusnya Revolusi}

Novel Ayyām fì Bābā 'Amrū mengambil latar waktu ketika awal revolusi Suriah meletus. Adapun latar tempat dalam novel ini adalah beberapa kota seperti Damaskus, Homs, dan Hama. Novel ini mengambil penceritaan dari tokoh Aku sebagai tokoh utama. Tokoh Aku merupakan seorang lelaki Suriah yang telah lama meninggalkan Suriah dan kembali untuk mengunjungi keluarganya di Hama dan mengumpulkan berita untuk membuat film dokumenter mengenai revolusi Suriah. Saat ia kembali ke Suriah, aksi protes sudah menyebar ke beberapa kota yang dimulai dari Dar'a dan diikuti kota-kota lain seperti Homs, Hama, dan Idlib. Ia juga melihat banyak hal yang telah berubah di Suriah pasca meletusnya aksi demonstrasi untuk menuntut rezim tumbang. Militer di bawah perintah rezim melakukan beberapa tindakan represif terhadap rakyat untuk menekan aksi protes yang semakin menyebar ke kota-kota di Suriah.

Tokoh Aku berniat kembali ke kampung halamannya di Hama. Dari Damaskus ia menaiki bus menuju Hama. Akan tetapi, dalam perjalanan bus yang dia tumpangi ditahan oleh militer dan diperiksa. Tokoh aku diturunkan dari bus karena tidak membawa kartu identitas Suriah.

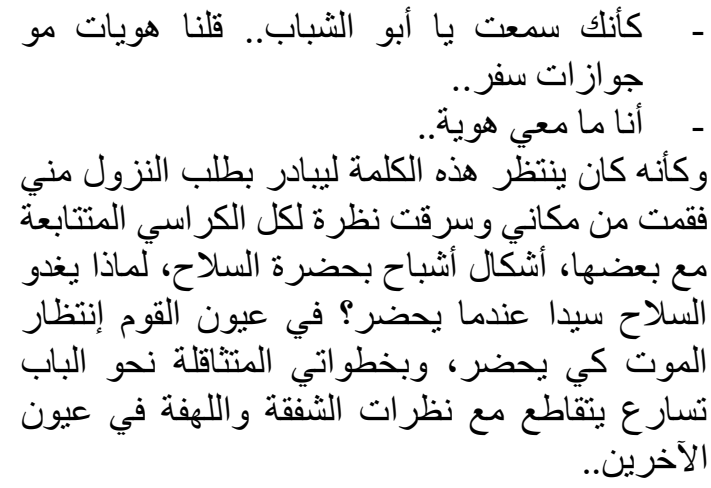

(Maksūr, 2013:61) 
"Sepertinya kamu sudah mendengar, Pak tua. Kami mengatakan kartu identitas, bukan passport."

"Aku tidak memiliki kartu identitas.."

Dia seakan menunggu kalimat ini keluar untuk memerintahkanku untuk turun dari bus. Aku kemudian berdiri dan melemparkan pandangan ke setiap bangku yang berurutan. Para pemumpang seperti melihat hantu karena adanya senjata. Kenapa senjata selalu menjadi tuan ketika dia ada? Di setiap tatapan rakyat ada penantian maut agar segara datang. Dengan langkah yang berat aku menuju pintu bus, diiringi oleh tatapan iba dan ketakukan dari mata para penumpang.'

Setelah diturunkan dari bus oleh anggota militer, tokoh Aku kemudian dibawa ke kantor pemeriksaan. Di sana ia diperiksa dan diinterogasi oleh kepala petugas. Tas dan passportnya ditahan oleh petugas. Ia dan beberapa tahanan lainnya kemudian dibawa ke kantor mukhabarat (Inteligen Angkatan Udara) menggunakan mobil bak.

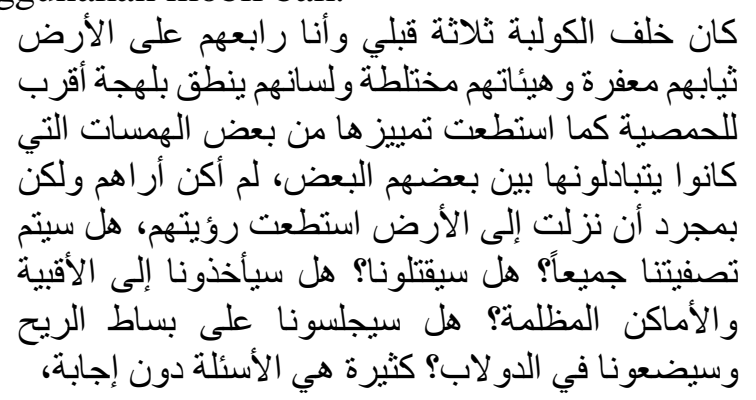
(Maksūr, 2013:65)

'Di belakang kursi itu ada tiga orang yang datang sebelum aku, aku keempat. Baju mereka terlihat mahal. Tubuh mereka campuran. Mereka mengucapkan logat yang mirip dengan logat Homs seperti yang bisa aku dengar dari ucapan semangat yang saling mereka ucapkan. Aku belum melihat mereka, tetapi setelah aku turun ke tanah (duduk) aku dapat melihat mereka. Apakah kami akan dimusnahkan? Apakah mereka akan membunuh kami? Apakah mereka akan membawa kami ke gudang dan tempat-tempat yang gelap? Apakah mereka akan mendudukkan kami di atas bisāti arrīh dan meletakkan kami di atas dūlab?

\section{Semuanya adalah pertanyaan tanpa jawaban.'}

Dari kutipan di atas, tokoh aku melihat tiga orang yang terlebih dahulu ditahan sebelum dirinya. Tokoh aku mempertanyakan apa yang akan dilakukan oleh militer terhadap dirinya dan tahanan lain. Apakah mereka akan dilenyapkan atau mereka akan dibawa ke tempat-tempat penyiksaan militer yang tersebar di seluruh negeri. Rezim Al-Assad memberlakukan peraturan darurat dengan memungkinkan menangkap rakyat tanpa pengadilan, membatasi pertemuan publik, dan pengawasan ketat yang dilakukan oleh militer. Selain itu, warga sipil juga akan diadili di penjara militer. Di penjara militer, warga sipil akan didudukkan pada bisāt ar-rīh yang merupakan pola penyiksaan di penjara militer, yakni dengan mengikat tahanan pada papan datar dengan tangan dan kaki diikat dan kepala menggantung di udara. Papan datar ini dapat ditekuk menjadi setengah hingga wajah tahanan dapat menyentuh kaki mereka yang menyebabkan mereka tidak dapat melawan. Adapun dūlab merupakan pola siksaan dengan tahanan terlipat di pinggang dan kepala, leher, dan kaki mereka dimasukkan ke dalam ban mobil sehingga mereka tidak bisa bergerak dan tidak dapat melindungi diri dari pemukulan di punggung, kaki, dan kepala termasuk dengan tongkat dan cambuk (Human Right Watch, 2012:21-25).

Orang-orang yang ditangkap bersama tokoh aku kemudian diangkut menggunakan sebuah mobil bak terbuka dan dibawa ke kantor cabang Mukhābarāt al-jawwiyah (Intelijen Angkatan Udara) di Homs. Setelah aksi protes di Dar'aa terjadi, militer menangkap demonstrandemonstran dan ditahan di penjara-penjara militer. Untuk mengatur ribuan orang yang ditangkap dalam demonstrasi anti rezim, militer menggunakan beberapa tempat seperti stadium, kantor militer, sekolah, dan rumah sakit untuk mengumpulkan tahanan sebelum kemudian dibawa ke kantor-kantor Mukhābarāt. Sejak awal aksi protes terhadap rezim, sekitar sepuluh ribu orang ditangkap secara sewenang-wenang, penahanan dengan tidak sah, penghilangan paksa, perlakuan buruk, dan penyiksaan menggunakan berbagai fasilitas dalam ruang 
tahanan di pusat-pusat penyiksaan yang tersebar di seluruh Suriah (Human Right Watch, 2012:2).

Tokoh Aku dan sekitar dua puluh empat orang lain yang ditangkap oleh militer kemudian dibawa ke penjara bawah tanah untuk diinterogasi. Di penjara-penjara militer Suriah, terdapat sebuah ruangan kecil berukuran $3 \times 4$ meter diisi oleh dua puluh lima orang. Hal ini tidak memenuhi standar dan berbeda dengan penjara di Eropa yang berukuran 4x5 meter dan hanya diisi oleh lima orang tahanan. Orang-orang yang ditangkap dan dibawa ke penjara milik Mukhābarāt al-jawwiyah di Homs. Para tahanan kemudian dikumpulkan di dalam sebuah ruangan kecil. Militer juga menakut-takuti rakyat dengan senjata yang mereka miliki. Militer bahkan tidak segan menembak tahanan yang dianggap menghina presiden.

Tahanan di kantor Mukhābarāt aljawwiyah cabang Homs kemudian dibawa ke ruang bawah tanah untuk diinterogasi. Mereka dipukuli dan disiksa menggunakan berbagai cara dan berbagai alat. Tokoh aku juga mendapatkan siksaan karena dia dituduh bernama Mahmud Sa'id yang merupakan salah satu oposisi. Ia ditangkap karena menyelundupkan senjata untuk oposisi. Menurut Human Right Watch (2012:2) intelijen Suriah mengandalkan undang-undang darurat dalam menangkap rakyat tanpa surat penangkapan dan melakukan penyiksaan di ruang tahanan. Interogator, penjaga, dan petugas menggunakan berbagai macam siksaan terhadap tahanan, termasuk pemukulan bertubi-tubi yang dilakukan menggunakan alat seperti pentungan dan kabel. Mereka juga meletakkan tahanan dalam posisi stress yang menyakitkan selama beberapa waktu. Mereka juga menyiksa tahanan menggunakan sengatan listrik, melakukan serangan seksual, mencabut kuku, dan menghina tahanan.

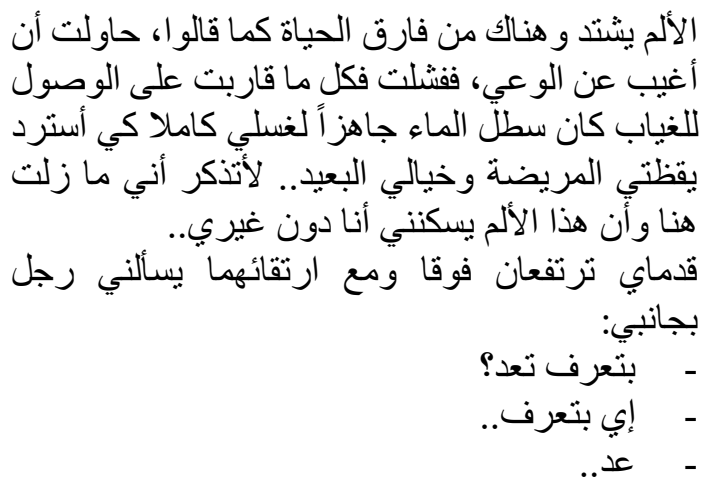

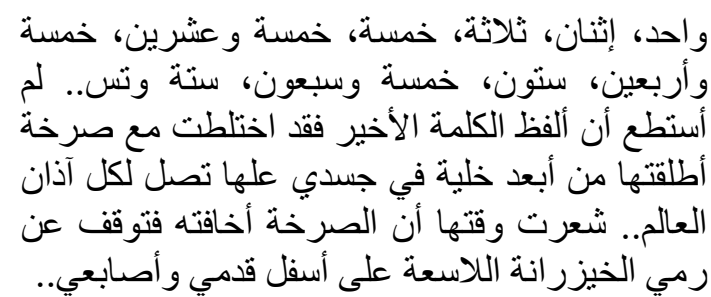

(Maksūr, 2013:130)

'Rasa sakit terasa semakin bertambah. Ada juga yang telah meninggal seperti yang mereka katakan. Aku berusaha untuk pingsan berkali-kali tetapi gagal. Setiap kali aku hampir pingsan, seember air siap disiramkan ke seluruh tubuhku agar kesadaran dan khayalanku kembali. Agar aku mengingat bahwa aku masih di tempat ini dan bahwa rasa sakit ini bukan orang lain yang merasakan. Kedua kakiku diangkat ke atas. Sambil mengangkatnya, seorang laki-laki di sampingku bertanya;

- Kamu bisa berhitung?

- Iya

- Berhitung!

Satu, dua, tiga, lima, dua puluh lima, empat puluh lima, enam puluh, tujuh puluh lima, sembilan pu... aku tidak mampu melanjutkan hitungan terakhir karena bercampur dengan teriakan yang aku keluarkan karena sengatan di tubuhku. Kencangnya teriakan itu terdengar oleh seluruh telinga yang ada di dunia. Aku merasa ketika teriakanku keluar, sengatan alat kejut di kaki dan tanganku pun berhenti.'

Dari kutipan tersebut di atas, tokoh aku mengalami penyiksaan di penjara militer sebagai pengganti seorang lelaki bernama Mahmud asSa'id karena telah membawa senjata. Dari kutipan di atas terlihat bahwa penjara-penjara militer di Suriah merupakan tempat yang menyeramkan. Banyak tawanan yang meninggal karena berbagai pola penyiksaan yang dilakukan oleh algojo di penjara. Para tahanan diikat di sebuah tiang, mereka ditelanjangi, dipukul, ditendang, disetrum menggunakan alat kejut, disiram air, mata mereka ditutup, dan tidak diberi makanan yang layak (Human Right Watch, 2012:15-16). Penyiksaan yang dilakukan di 
penjara umumnya terjadi dari jam sembilan malam hingga fajar tiba.

Tokoh aku kemudian terpaksa mengakui bahwa dia adalah Mahmud Sa'id yang dituduh oleh militer agar ia dibebaskan dari siksaan yang dialami. Setelah ditahan selama 60 hari, tokoh aku dibebaskan oleh militer. Ia kemudian menghubungi saudara Wasim, teman dia di penjara, dan menuju Baba 'Amru, Homs. Baba 'Amru merupakan sebuah wilayah di Homs yang merupakan basis dari Free Syrian Army. Free Syrian Army adalah oposisi rezim Bashar alAssad. Di Baba 'Amru terdapat kantor pemberitaan milik oposisi yang digunakan untuk menyebarkan berita mengenai revolusi Suriah. Tak lama setelah ia tiba di Baba 'Amru, tempat itu kemudian diserang oleh militer Suriah menggunakan bom dan tank.

$$
\begin{aligned}
& \text { أقف فور اً وأطل من الشبالك لأرى قو افلا من الدبابات }
\end{aligned}
$$

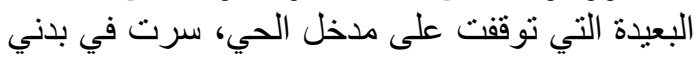

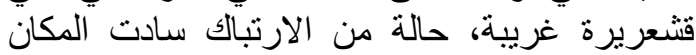

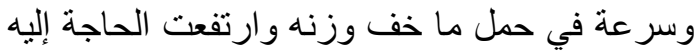

$$
\begin{aligned}
& \text { ثم هروب مدروس بطربقة سريعة لنصبح كلنا خارجا }
\end{aligned}
$$

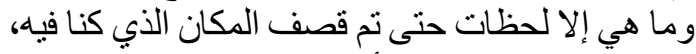

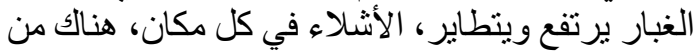

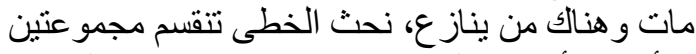

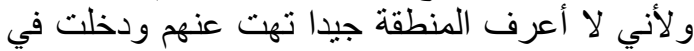

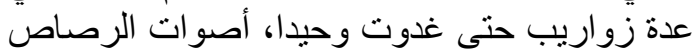

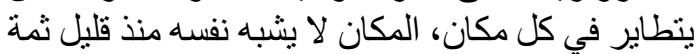

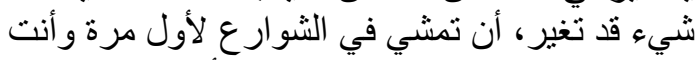

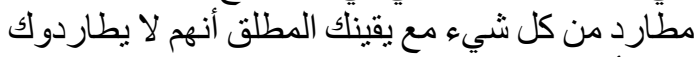

$$
\begin{aligned}
& \text { قفط لأنك موجود هنا بمحض الصدفة المطلقة }
\end{aligned}
$$

(Maksūr, 2013:91)

'Aku segera berdiri dan melongok ke arah jendela dan melihat sekelompok tank dari kejauhan yang berhenti di pintu gerbang pemukiman. Badanku tiba-tiba terasa menggigil. Kebingungan dan ketakutan memenuhi tempat itu dan orang-orang segera membawa barang-barang yang ringan dan dibutuhkan. Orang-orang kemudian melarikan diri dengan cepat hingga kami semua berada di luar. Hanya beberapa saat hingga bangunan tempat kami tadi telah hancur karena bom. Debu meninggi dan beterbangan. Pembantaian terjadi di mana-mana. Di sebelah sana orang meninggal, di sebelah sana orang panik. Kami terbagi menjadi dua barisan. Karena aku tidak mengenal tempat ini, aku mengikuti mereka memasuki beberapa barisan hingga aku tersisa sendirian. Suara tembakan terdengar di mana-mana. Tempat ini tidak lagi sama dengan sebelumnya sejak ada yang berubah. Sebelumnya kamu berjalan di jalan-jalan ini, sekarang kamu berlari dari segalanya dengan yakin bahwa mereka tidak mengejarmu karena siapa kamu, melainkan karena kamu kebetulan ada di tempat ini.'

Serangan militer di Baba 'Amru menewaskan banyak orang. Tidak hanya dari pihak oposisi, tetapi juga rakyat sipil banyak yang menjadi korban. Bangunan-bangunan penting juga runtuh karena serangan bom dari militer, termasuk rumah sakit. Karena itu, rakyat sipil membuat rumah sakit darurat untuk menyelamatkan korban pengeboman dan tembakan militer. Selain itu, beberapa gadis juga menjadi korban pelecehan seksual yang dilakukan oleh militer Suriah. Militer memperkosa beberapa gadis dan memukul salah satu di antara mereka hingga tewas.

Tokoh aku berada di Homs selama beberapa hari untuk mengumpulkan data-data dan bahan untuk membuat film dokumenter mengenai revolusi Suriah. Tokoh aku mewawancarai anggota Free Syriah Army dan rakyat sipil di Baba 'Amru untuk mengetahui pandangan mereka mengenai revolusi Suriah. Dalam hal ini, rakyat Suriah memiliki pendapat yang berbeda-beda. Sebagian setuju untuk melakukan revolusi dan aksi protes yang damai, sebagian lagi setuju untuk mengangkat senjata, sebagian lagi berpandangan bahwa tidak perlu ada revolusi, sebagian besar lebih memilih diam karena takut dan tidak peduli, sedangkan sebagian lagi memilih pergi ke luar negeri untuk mencari keamanan.

$$
\begin{aligned}
& \text { ثلاثة أيام من اللقاءات المنواصلة والنقاثات العديدة }
\end{aligned}
$$

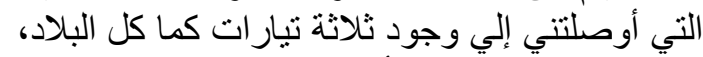

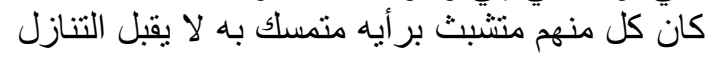

$$
\begin{aligned}
& \text { عنه إطلاقا. } \\
& \text { مصطفى شاب لم يتجاوز الثناثين من عمره تقريبا يقف الفقال } \\
& \text { ضد العمل العسكري فهو مع النظاهر السلمي و النضال }
\end{aligned}
$$

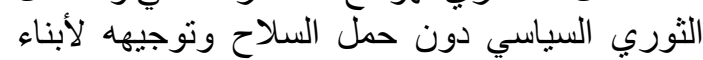

$$
\begin{aligned}
& \text { المؤسسة العسكرية أو الأمنية وحجته في ذلكية للك عدم }
\end{aligned}
$$

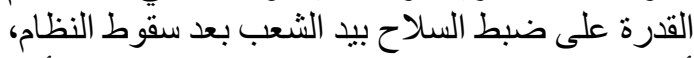

$$
\begin{aligned}
& \text { أما عمر فقد حمل السلاح منذ وقع الاستهداف الأول بـال }
\end{aligned}
$$


للمنطقة معتبر ا أن هذا النظاهم لا يذهب إلا بالقوة، بينما

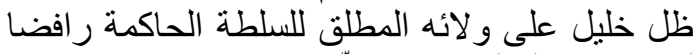

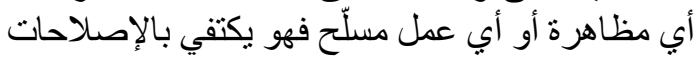

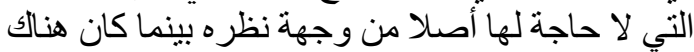

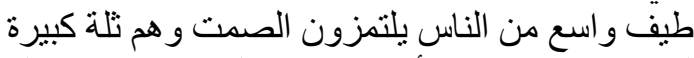

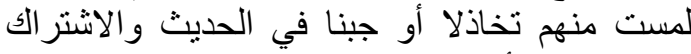

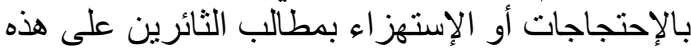
الأرض بينما هرب قسم آخر خارج الإنداء البلاد.

(Maksūr, 2013:170)

'Selama tiga hari melakukan pertemuan berkelanjutan dan diskusi berkali-kali dengan mereka mengantarkan aku pada pemahaman ada tiga kelompok seperti yang terjadi di seluruh negeri. Setiap kelompok kukuh dengan pendapat masingmasing dan tidak menerima kritik mengenai hal tersebut sama sekali.

Musthafa, seorang pemuda yang belum berumur lebih dari 30 tahun, menolak tindakan represif militer dan berada di barisan pendukung aksi demonstrasi damai dan upaya revolusi politik tanpa aksi mengangkat senjata dan mengarahkannya ke militer dan anggota keamanan. Dia berpendapat bahwa rakyat tidak memiliki kekuatan untuk mengangkat senjata setelah runtuhnya rezim. Adapun Umar telah mengangkat senjata sejak awal terjadinya aksi protes dengan alasan bahwa rezim tidak akan tumbang kecuali dengan kekuatan. Hal ini berbeda dengan Khalil yang menunjukkan kesetiaannya yang mutlak terhadap rezim pemerintah dan menolak aksi demonstrasi dan aksi konflik bersenjata. Dia merasa cukup dengan reformasi yang sebenarnya tidak terlalu dibutuhkan menurut pandangannya. Sedangkan sebagian besar masyarakat lebih memilih diam, sebagian besar karena tidak peduli dan karena mereka takut untuk ikut mengeluarkan suara dan ikut dalam aksi protes, sebagian lagi mengejek demonstran yang menuntut revolusi di tanah Suriah. Adapun sebagian lagi memutuskan untuk melarikan diri ke luar negeri.'

Setelah beberapa waktu di Baba 'Amru, Homs, tokoh Aku kemudian menuju Hama diantar oleh tiga orang anggota Free Syrian
Army. Dari kejauhan dia mendengar suara ledakan bom dan peluru. Setiba di Hama, tokoh Aku mendapati Hama telah menjadi puing-puing tak berpenghuni karena serangan yang dilancarkan oleh rezim al-Assad. Ia mendapati rumah-rumah yang dia kenali dulu telah rata dengan tanah. Ia juga mendapati anak-anak kecil yang dulu dia kenal telah mengangkat senjata menjadi oposisi rezim. Tak lama setelah tiba di Hama, tokoh aku juga mengalami ketakukan karena serangan yang dilancarkan oleh rezim alAssad di Hama pada malam hari.

$$
\begin{aligned}
& \text { الظلام الدامس بطبق على المكان و أصوات الاستغفار }
\end{aligned}
$$

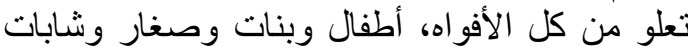

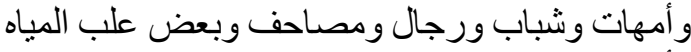

$$
\begin{aligned}
& \text { وأصوات الانفجارات تقترب والرواص واص في كل }
\end{aligned}
$$

(Maksūr, 2013:162)

'Kegelapan menyelimuti tempat itu dan suara istighfar diteriakkan oleh setiap lisan. Anak-anak, anak-anak perempuan, anak kecil, gadis-gadis, ibu-ibu, pemuda, laki-laki dewasa, mushaf-mushaf, botolbotol air, suara ledakan yang semakin mendekat, dan suara letusan senapan di setiap tempat.'

Dari kutipan tersebut di atas, terlihat bahwa rakyat panik dan ketakutan terhadap serangan bom dan tembakan yang dilancarkan rezim. Kemarahan rezim terhadap oposisi membuat rezim tidak hanya menyerang oposisi tetapi juga rakyat sipil. Rakyat-rakyat sipil seperti anak-anak, wanita, dan orang tua menjadi korban atas pembalasan rezim terhadap oposisi.

Konflik yang tak kunjung selesai antara rezim dan oposisi bahkan semakin buruk membuat sebagian besar rakyat Suriah mengungsi ke beberapa negara terdekat. Tercatat jutaan jiwa telah meninggalkan Suriah untuk mencari perlindungan ke beberapa negara tetangga Suriah. Rakyat Suriah mengungsi untuk mencari tempat berlindung dari konflik bersenjata yang tidak kunjung berakhir. Krisis politik dan keamanan yang dialami rakyat Suriah membuat mereka mengungsi ke beberapa negara terdekat, seperti Yordania dan Turki. Rakyat Suriah bahkan berusaha melewati laut untuk mengungsi ke Yunani. 
Relasi Antara Realita Sosial Suriah dan Novel Ayyām fì Bāba 'Amrū

Novel Ayyām fì Bābā 'Amrū menggambarkan dengan jelas realita sosial yang terjadi di Suriah pada masa awal Arab Spring melanda Suriah. Novel ini dapat dikatakan sebagai dokumen sosial budaya karena memperlihatkan dengan jelas apa yang dialami rakyat Suriah di bawah kepemimpinan rezim Bashar al-Assad. Perlakuan rezim al-Assad dan militer yang represif terhadap demonstran juga digambarkan dalam novel ini. Dalam novel ini, Maksūr tidak membuat perumamaan atau penggambaran tokoh lain dengan mengarah kepada kenyataan. Akan tetapi, dia menggambarkan dengan jelas bagaimana rakyat menginginkan kebebasan dari rezim al-Assad yang telah berkuasa kurang lebih 40 tahun. Ia juga menggambarkan sesuai kenyataan mengenai seorang penyanyi bernama Ibrahim alQasyusyi yang menyanyikan lagu Irhal ya Bashar untuk menyemangati rakyat Suriah untuk melakukan revolusi. al-Qasyusyi kemudian ditemukan terbunuh di suatu pagi dengan leher tergorok dan pita suaranya dicabut. Rakyat mempertanyakan pembunuh al-Qasyusyi, sebagian mengatakan bahwa al-Qasyusy dibunuh oleh rezim karena menyanyikan lagu yang membuat rakyat melakukan revolusi.

Dalam novel Ayyām fì Bābā 'Amrū, Maksūr menggambarkan homologi antara novel dan realita. Ia menunjukkan ketakutan, kepanikan, penyiksaan, pembunuhan, pelecehan seksual, penderitaan yang dialami oleh rakyat Suriah pasca meletusnya revolusi di Suriah. Ia juga menyebutkan dengan jelas penyiksaan dan perlakuan militer terhadap rakyat Suriah. Ia juga menggambarkan mengenai penyiksaan yang dialami para tahanan di penjara-penjara militer mukhābarāt. Hal tersebut memiliki kesejajaran dengan beberapa buku yang menuliskan bahwa militer Suriah terkenal represif, mereka menangkap dan menyiksa rakyat yang terlibat dalam demonstrasi yang menuntut rezim Bashar al-Assad tumbang.

\section{KESIMPULAN}

Novel Ayyām fi Bābā 'Amrū karya Abdullah Maksūr ini merupakan salah satu novel yang menggambarkan situasi yang sedang dialami oleh rakyat Suriah yang mengalami perang sipil. Novel ini mengambil latar waktu pada awal-awal meletusnya revolusi di Suriah. Novel ini dapat disebut sebagai salah satu novel yang memenuhi syarat novel sosiologi sastra Alan Swingewood, yakni karya sastra sebagai cermin sosial. Hal ini disebabkan novel ini memberikan gambaran, cerminan sosial, yang merefleksikan situasi masyarakat pada masa karya sastra ini diciptakan. Sebagai cermin sosial, novel ini menunjukkan kepada pembaca konflik yang terjadi di Suriah pasca meletusnya revolusi Suriah. Novel ini menggambarkan kondisi yang terjadi dan dialami oleh rakyat Suriah sebelum dan setelah meletusnya revolusi Suriah. Dalam novel ini, penulis menggambarkan rezim yang telah berkuasa selama kurang lebih 40 tahun, korupsi yang terjadi di hampir seluruh bagian pemerintahan. Selain itu, penangkapan dan pembunuhan anggota Ikhwan al-Muslimin dan masyarakat yang dianggap terlibat dengan Ikhwan alMuslimin yang terjadi di Hama pada Februari 1982 menjadi salah satu penyebab kebencian terhadap rezim dan keinginan untuk menuntut rezim tumbang.

Adapun kondisi rakyat Suriah yang banyak diangkat dalam novel ini adalah pasca meletusnya revolusi. Dalam novel ini digambarkan bahwa rakyat Suriah mengalami intimidasi dan kekerasan dari militer. Rakyat juga banyak yang ditangkap oleh militer dengan berbagai alasan, salah satunya karena melakukan demonstrasi. Rakyat yang ditahan oleh militer kemudian disiksa di penjara Mukhābarāt alJawwiyah (intelijen angkatan udara), salah satu badan intelijen yang paling ditakuti oleh rakyat Suriah. Setelah gelombang demonstrasi tidak dapat dibendung, rezim kemudian menyerang beberapa kota seperti Dar'a, Homs, dan Hama dengan bom, tank, dan peluru. Karena serangan ini, banyak rakyat Suriah yang meninggal dunia. Selain itu, beberapa gadis Suriah juga mengalami pelecehan seksual yang dilakukan oleh anggota militer. Rakyat yang tidak tahan dengan kondisi Suriah yang mengalami konflik bersenjata kemudian memutuskan untuk mengungsi ke beberapa negara, seperti Yordania dan Turki.

Relasi antara karya sastra dan realita sosial yang terjadi di Suriah terlihat jelas dalam 
novel ini. Pengarang menggambarkan kejadiankejadian yang memperlihatkan homologi antara karya sastra dan realita sosial. Pengarang bahkan menyebutkan beberapa kejadian yang nyata terjadi, seperti pembunuhan Ibrahim AlQasyusyi, seorang penyanyi yang berasal dari Hama, yang menyanyikan lagu pembangkit revolusi dengan judul Irḥal yā Bashār dan serangan di Baba 'Amru yang merupakan basis FSA, oposisi rezim al-Assad.

\section{DAFTAR PUSTAKA}

Damono, Sapardi Djoko. 1979. Sosiologi Sastra: Sebuah Pengantar Ringkas. Jakarta: PPB Depdikbud.

Darraj, Susan Muaddi. 2005. Bashar al-Assad. Philadelphia: Chelsea House Publisher.

Haran. VP. 2016. Roots of The Syrian Crisis. IPCS Report.

Junus, Umar. 1986. Sosiologi Sastera: Persoalan Teori dan Metode. Kuala Lumpur: Dewan Bahasa dan Pustaka.

Kuncahyono, Trias. 2013. Musim Semi di Suriah: Anak-Anak Sekolah Penyulut Revolusi. Jakarta: Kompas.

Lesch, David W., Haas Mark L, dll. 2013. The Arab Spring: Change and Resistance. Philadelpia: Westview.

Maksūr, Abdullah. 2013. Ayyām fì Bābā 'Amrū. Cetakan kedua. Ardan: Daar Fadaat.

Ratna, Nyoman Kutha. 2009. Teori, Metode, dan Teknik Penelitian Sastra. Cetakan Keduabelas. Yogyakarta: Pustaka Pelajar.

-----------------------. 2013. Paradigma Sosiologi Sastra. Cetakan Keempat. Yogyakarta: Pustaka Pelajar

Phillips, Douglas A. 2010. Syria. New York: InfoBase Publishing.

Reese, Erlich. 2014. Inside Syria: The Backstory of Their Civil War and What the World Can Expect. New York: Prometheus Books.

Sangidu. 2004. Penelitian Sastra: Pendekatan, Teori, Metode, Teknik, dan Kiat. Yogyakarta: Unit Penerbitan Sastra Asia Barat.

Swingewood, Alan dan Diana Lorenson. 1972. The Sociology of Literature. London: Paladine.

\section{Jurnal}

Amnesty International. 2016. Military Prison: Human Slaughter House. Diunduh dari https://www.amnestyusa.org/files/human slaughterhouse.pdf pada 16 Agustus 2018 pukul 17.05 .

Borshchevkaya, Anna. 2010. "Sponsored Corruption and Neglected Reform in Syria”. Middle East Quarterly. Hal 4150.

Fahham, A. Muchaddam dan A.M. Kartaatmaja. 2014. "Konflik Suriah: Akar Masalah dan Dampaknya". Jurnal Politica. Vol. 5 No. 1 Hal. 37-60.

Human Right Watch. 2012. Torture Archipelago: Arbitrary Arrests, Torture, and Enforced Disappearances in Syria's Underground Prison Since March 2011. Diunduh dari https://www.hrw.org/sites/default/files/r eports/syria0712webwcover_0.pdf

- Setiawati, Siti Muti'ah. 2012. "Pergolakan Perang Suriah: Masih Adakah PanArabisme dan Pan-Islamisme?". Jurnal CMES. Vol 5. No. 1. Hal 4-17. 